\title{
CHALLENGES IN THE USE OF INFORMATION TECHNOLOGY IN PROCESSING HEALTH INFORMATION IN RESOURCE LIMITED SETTINGS: A COMPREHENSIVE SYSTEMATIC REVIEW
}

\author{
M. Bimerew \\ School of Nursing, \\ University of the Western Cape \\ mbimerew@uwc.ac.za
}

\section{ABSTRACT}

The use of information technology in processing and utilising health information has significant health care outcomes. Its use in the assessment, diagnosis and management of health problems through access to relevant health information is crucial. The aim of this review was to identify the use of information technology in processing and utilising health information in low resource settings. A comprehensive systematic review focusing on resource limited settings was conducted. The review identified the following challenges in the use of information technology in resource limited settings: lack of health information system and networking; limited knowledge and skills; lack of information users' participation; unavailability of standardised health indicators and poor quality information processing. Combining manual and technology assisted information processing system in less resource settings is essential in transforming and promoting the utilisation of health information. The capacity development training, involvement of community professional nurses and midwives in the design and development of health information system for processing and utilisation, and creating an enabling environment could help overcome the challenges in the use of information technology in low resource settings.

Keywords: challenges, information technology use, processing health information, resource limited settings

\section{UNISA $\cong$}




\section{INTRODUCTION}

Health information technology is the application of information processing involving computer hardware and software that deals with the storage, retrieval, sharing and use of healthcare information in decision making (Goldschmidt, 2005; Haux, 2006). The use of information technology has significant impact on health care outcomes. It enables assessment, diagnosis and management of health problems, access to health literature, online journals, books and databases, and supports home-based caregivers to provide quality care for individual patients in their own homes (World Health Organization, 2005). Furthermore, the use of computers and cellphones is currently widely spreading even to less developed remote areas, enabling individuals to access technology for their health-related problems (Jensen, King, Guntzviller \& Davis, 2010). The use of information technology in health care delivery assist access to timely, reliable and accurate early information in outbreaks for preventing and reporting outbreaks, especially in economically vulnerable countries (Revere et al., 2007). It also facilitates the day-to-day nursing health care management, such as patient information, sharing vertically and horizontally with other health care providers and information transfer from hospital to Primary Health Care (PHC) for continuity of care and reminders to patients to take their medication regularly, which reduces readmission (Revere et al., 2007).

One of the most important aspects of health information technology is the ability to create the relationship between doctors, nurses and patients. It creates mutual understanding, building trust and loyalty, effective communication, involvement in decision making, satisfaction and better health-related outcomes (Richard \& Ronald, 2008).

However, there are still noticeable challenges in the use of information technology on processing and utilising health information in resource limited settings. There are inadequate infrastructure and functioning systems, and lack of users understanding the importance of health information technology in the health services in developing countries (Littlejohn, Wyatt \& Garvican, 2003). Garrib et al. (2008) identified that culture of information use was weak, while the European Commission (2004) suggests the importance of standardising health information technology, such as the content and structure of patient summary information. Patient summary information has been seen as the most appropriate way to establish electronic health (eHealth) information exchange. A patient summary includes five main points: patient history, allergies, active problems (diagnosis), test results, and medications (Hayrinen, Saranto \& Nykänen, 2008). Another challenge is the format of information; it is realized that information is of little value if it is not available in formats that meet the needs of users (WHO, 2008). Therefore, dissemination and communication are essential attributes of the Health Information System (HIS). The aim of the article was to identify the use of information technology in processing and utilising health information in a resource limited settings. 


\section{METHODS}

\section{Study selection}

All relevant peer-reviewed and non-peer-reviewed papers, published and unpublished grey literature, conference/workshop proceedings and government policy guidelines papers were included in the review. Two reviewers independently selected the articles for review. The keywords used were health information and resource limited settings, health information and challenges, use of health information technology. Original articles published in English between 2004 and 2014 were cited. All geographical locations were included in the search, as far as the focus was mainly on resource limited settings. Studies conducted on public health facilities such as primary health care, district health service, community health centres, clinics and private hospitals were included in the review.

\section{Sources and research strategy}

A review was started by defining and developing the key questions or words that specified the research question being addressed and the method that would be used to perform the review. Hand searches for reference lists of pertinent reviews and studies, as well as abstracts from relevant conferences and organisations were consulted. Experts in the field were contacted as was necessary during the process of systematic review. The electronic search strategies were gradually refined for each database. Bibliographic hand searching, conference proceedings as well as other databases, such as medical and nursing health informatics, and computer models for health information recording systems were also searched.

Experienced librarians were consulted to assist in searching current publications from the databases or search strategies. A summary of the retrieved documents, which included an elaboration of the theoretical perspective, a description of the methodology and a statement of major findings were drawn up. The systematic review was conducted using peer-reviewed articles that were retrieved using search engines on PUBMED, EMBASE, CINAHL, and Medline, JBI library systematic review, PsychINFO and the Cochrane Library. HIS journals were searched for articles not indexed in the databases. Databases were subsequently searched by the researchers to find any other appropriate articles not found through the database search. The last step was a general internet search using the Google engine. The search strategy key terms included: information technology and processing health information, information technology in resource limited settings, challenges in health information processing, medical electronic record information system infrastructure and challenges, health information processing and utilisation, application of ICT in less income countries, and development of HIS in developing countries. 


\section{RESULTS}

Two reviewers independently appraised and extracted detail of selected articles using the standard data extraction template. The data extraction template incorporated methodology, methods, types of participants, the method of data analysis used in primary studies and conclusions. Discrepancies were resolved by consensus. The integrated synthesis method to summarise the findings was used. Systematically identified themes that emerged from the publications were recorded on spreadsheets with a column for each of the key issues noticed.

A total of 972 papers were retrieved by title. Of the total retrieved $75(7.72 \%)$ were identified as potentially relevant to the review on the basis of abstracts. After reviewing the whole text, of the 75 papers identified as potentially relevant, 18 (24\%) articles were considered highly relevant to the purpose of this review. From 18 articles selected, through screening the articles based on research and text papers produced 13 research papers and 5 texts/expert and policy guidelines papers. The following diagram illustrates the screening process of the study and text papers identified through searching different databases. The independently extracted data were compared with the help of another independent reviewer who assisted with the review process. Experts were also consulted for the methodological rigor of the review process.

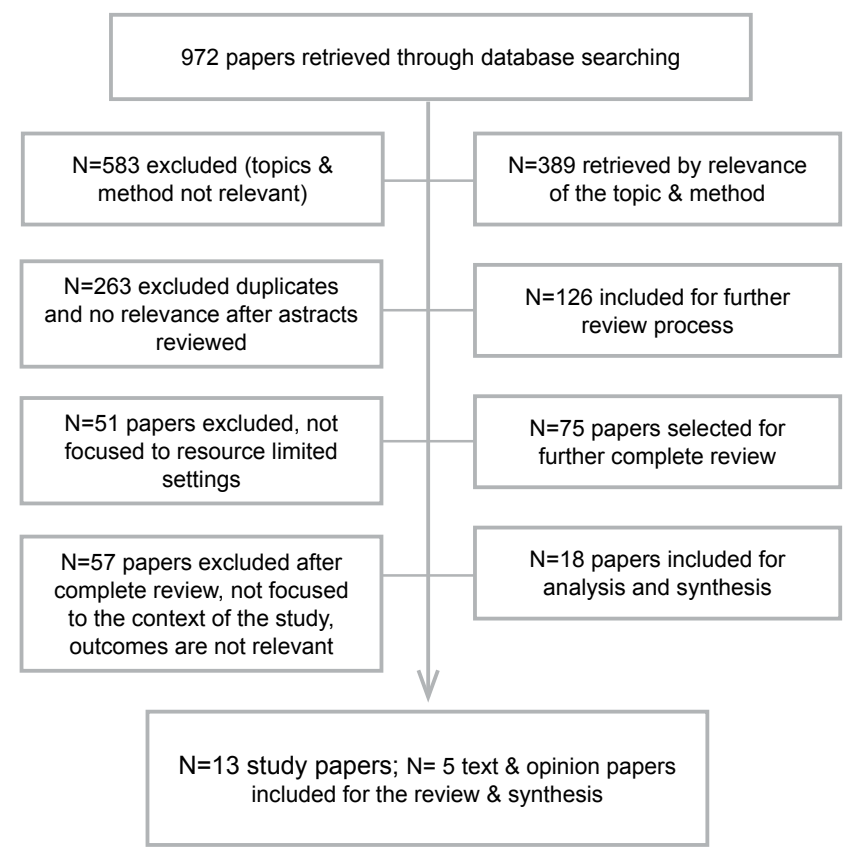

Figure 1: Illustrates the screening process and criteria for selection of papers 


\section{DATA EXTRACTION}

Two reviewers (M.S., M.R.) independently extracted study characteristics using data extraction form. They summarised the overall findings, conclusions and recommendations of the authors as indicated in the table below.

Table 1: Extraction of data from selected research papers

\begin{tabular}{|c|c|c|c|c|c|}
\hline Citation & Study design & Purpose & Sample size & Relevant findings & Recommendation \\
\hline $\begin{array}{l}\text { Chetley et al., } \\
2006 a\end{array}$ & $\begin{array}{l}\text { Key informant } \\
\text { interview }\end{array}$ & $\begin{array}{l}\text { To explore } \\
\text { constraints in } \\
\text { using ICT in } \\
\text { developing } \\
\text { countries, }\end{array}$ & $\begin{array}{l}\text { No sample } \\
\text { size indicated }\end{array}$ & $\begin{array}{l}\text { Main constraints and } \\
\text { challenges were: } \\
\text { connectivity, content, } \\
\text { capacity, community, } \\
\text { commerce, culture, } \\
\text { cooperation and } \\
\text { capital. }\end{array}$ & $\begin{array}{l}\text { involve users } \\
\text { in the design by } \\
\text { demonstrating the } \\
\text { benefits; strengthen } \\
\text { monitoring and } \\
\text { evaluation; share } \\
\text { learning about what } \\
\text { works and what } \\
\text { does not }\end{array}$ \\
\hline $\begin{array}{l}\text { Hendy et al., } \\
2005\end{array}$ & $\begin{array}{l}\text { Case studies } \\
\text { and in-depth } \\
\text { interviews }\end{array}$ & $\begin{array}{l}\text { To explore } \\
\text { perceived } \\
\text { barriers and } \\
\text { opportunities } \\
\text { to facilitate HIS } \\
\text { implementation }\end{array}$ & $\begin{array}{l}\text { Sample size, } \\
23 \text { senior } \\
\text { managers } \\
\text { and clinicians }\end{array}$ & $\begin{array}{l}\text { process of } \\
\text { implementation } \\
\text { was suboptimal, } \\
\text { low morale of } \\
\text { staff, resistance } \\
\text { to change, lack } \\
\text { of trust about the } \\
\text { implementation } \\
\text { schedules, short- } \\
\text { term benefits and } \\
\text { loss of electronic } \\
\text { functionality in the } \\
\text { short term, and poor } \\
\text { coordination }\end{array}$ & $\begin{array}{l}\text { Prioritise strategies } \\
\text { to improve } \\
\text { communication and } \\
\text { gain the cooperation } \\
\text { of frontline staff. } \\
\text { The importance } \\
\text { of socio-cultural } \\
\text { consideration in } \\
\text { the implementation } \\
\text { of IT }\end{array}$ \\
\hline $\begin{array}{l}\text { Odhiambo- } \\
\text { Otieno (2005) }\end{array}$ & $\begin{array}{l}\text { In-depth } \\
\text { interview, }\end{array}$ & $\begin{array}{l}\text { Evaluating } \\
\text { the existing } \\
\text { information } \\
\text { systems }\end{array}$ & $\begin{array}{l}\text { Purposive } \\
\text { sampling; } \\
\text { sample size } \\
(n=36)\end{array}$ & $\begin{array}{l}\text { Inadequate supply } \\
\text { of basic resources, } \\
\text { lack of integration, } \\
\text { no effective central } \\
\text { coordination, } \\
\text { fragmented; lack } \\
\text { of information } \\
\text { sharing among } \\
\text { stakeholders, large } \\
\text { amount of unused } \\
\text { data }\end{array}$ & $\begin{array}{l}\text { Design of DHIS } \\
\text { should involve } \\
\text { stakeholders and } \\
\text { integrate data from } \\
\text { all health service } \\
\text { providers } \\
\text { Infrastructure and } \\
\text { users' understanding } \\
\text { of implementation of } \\
\text { new system, }\end{array}$ \\
\hline
\end{tabular}




\begin{tabular}{|c|c|c|c|c|c|}
\hline $\begin{array}{l}\text { Garrib et al. } \\
(2008)\end{array}$ & $\begin{array}{l}\text { Semi- } \\
\text { structured } \\
\text { interviews } \\
\text { and } \\
\text { document } \\
\text { analysis }\end{array}$ & $\begin{array}{l}\text { Evaluating } \\
\text { the implemen- } \\
\text { tation of the } \\
\text { DHIS in rural } \\
\text { South Africa }\end{array}$ & $\begin{array}{l}\text { Convenience } \\
\text { sampling }\end{array}$ & $\begin{array}{l}\text { High perceived } \\
\text { burden of data. } \\
\text { Duplication of data } \\
\text { collection, several } \\
\text { separate data } \\
\text { collection tools. } \\
\text { Data missing, no } \\
\text { feedback, little } \\
\text { or no analysis, } \\
\text { interpretation or } \\
\text { utilisation. Poor } \\
\text { skills, lack of } \\
\text { understanding of } \\
\text { indicators and poor } \\
\text { numeracy skills }\end{array}$ & $\begin{array}{l}\text { Education and } \\
\text { skills training for } \\
\text { healthcare worker } \\
\text { and managers } \\
\text { on data analysis, } \\
\text { interpretation, and } \\
\text { data set concept } \\
\text { development, data } \\
\text { utilisation and } \\
\text { support and avoid } \\
\text { duplication }\end{array}$ \\
\hline $\begin{array}{l}\text { Vital Wave } \\
\text { Consulting } \\
(2009)\end{array}$ & $\begin{array}{l}\text { Interview, } \\
\text { case } \\
\text { studies and } \\
\text { secondary } \\
\text { data analysis }\end{array}$ & $\begin{array}{l}\text { Landscape } \\
\text { analysis of HIS } \\
\text { development } \\
\text { in developing } \\
\text { countries }\end{array}$ & $\begin{array}{l}\text { Multi-country } \\
\text { case studies }\end{array}$ & $\begin{array}{l}\text { Manual data } \\
\text { collection and } \\
\text { reporting system; } \\
\text { huge, redundant and } \\
\text { poor quality of data; } \\
\text { no integration with } \\
\text { other information; } \\
\text { fragmented system; } \\
\text { limited computer } \\
\text { literacy; and } \\
\text { sustainability issues }\end{array}$ & $\begin{array}{l}\text { Indicators to } \\
\text { determine the } \\
\text { common } \\
\text { information needs } \\
\text { and } \\
\text { sustainable } \\
\text { resources, } \\
\text { streamline data } \\
\text { collection } \\
\text { and invest on HIS } \\
\text { technology and } \\
\text { services }\end{array}$ \\
\hline Kalpa (2012) & $\begin{array}{l}\text { Secondary } \\
\text { data analysis }\end{array}$ & $\begin{array}{l}\text { Assessing the } \\
\text { role of health } \\
\text { information } \\
\text { technology in } \\
\text { the delivery } \\
\text { of health care } \\
\text { services in } \\
\text { India }\end{array}$ & & $\begin{array}{l}\text { Availability of } \\
\text { internet facility in } \\
\text { all organisational } \\
\text { areas, absence of } \\
\text { policy guidelines } \\
\text { and standards, } \\
\text { lack of proper } \\
\text { infrastructure and } \\
\text { competent human } \\
\text { resources were the } \\
\text { major challenges }\end{array}$ & $\begin{array}{l}\text { Formulation of } \\
\text { policy, standards } \\
\text { \& guidelines } \\
\text { to maintain the } \\
\text { quality, improve } \\
\text { the government } \\
\text { funding, to improve } \\
\text { infrastructure, } \\
\text { purchasing and } \\
\text { installing technology, } \\
\text { recruiting competent } \\
\text { staff or train existing } \\
\text { healthcare staff. }\end{array}$ \\
\hline $\begin{array}{l}\text { Hotchkiss, et } \\
\text { al., 2010) }\end{array}$ & $\begin{array}{l}\text { structured } \\
\text { interview } \\
\& \text { question- } \\
\text { naire }\end{array}$ & $\begin{array}{l}\text { Evaluating the } \\
\text { performance } \\
\text { of RHIS in } \\
\text { Uganda }\end{array}$ & $\begin{array}{l}110 \text { health } \\
\text { facilities in } \\
12 \text { districts of } \\
\text { Uganda }\end{array}$ & $\begin{array}{l}\text { High reliability } \\
\text { of PRISM in the } \\
\text { promotion of culture } \\
\text { of information } \\
\text { influence RHIS } \\
\text { tasks self-efficacy, } \\
\text { tasks competence } \\
\text { and motivation }\end{array}$ & $\begin{array}{l}\text { PRISM approach } \\
\text { can be effectively } \\
\text { used by RHIS } \\
\text { policy makers } \\
\text { and practitioners } \\
\text { to assess he } \\
\text { RHIS \& evaluate } \\
\text { its strengthen } \\
\text { intervention }\end{array}$ \\
\hline
\end{tabular}




\begin{tabular}{|c|c|c|c|c|c|}
\hline $\begin{array}{l}\text { Kapiriri \& } \\
\text { Bondy (2006) }\end{array}$ & Survey & $\begin{array}{l}\text { Determine } \\
\text { information } \\
\text { needs of health } \\
\text { practitioners \& } \\
\text { health planners } \\
\text { Uganda }\end{array}$ & $\begin{array}{l}610 \text { health } \\
\text { care workers, } \\
\text { planners } \\
\& \text { admini- } \\
\text { strators }\end{array}$ & $\begin{array}{l}\text { Personal } \\
\text { experience, } \\
\text { discussion with } \\
\text { colleagues, policy } \\
\text { and treatment } \\
\text { guidelines were } \\
\text { most influential } \\
\text { when making } \\
\text { decisions in health } \\
\text { care\& planning. } \\
\text { Lack of information } \\
\text { about distribution } \\
\text { benefits, segregated } \\
\text { demographic data } \\
\& \text { social values. } \\
\text { Internet and } \\
\text { library were the list } \\
\text { frequently is used. }\end{array}$ & $\begin{array}{l}\text { Health practitioners } \\
\text { lack some } \\
\text { information relevant } \\
\text { for decision making. } \\
\text { The variation in the } \\
\text { frequency use of the } \\
\text { different sources of } \\
\text { research information } \\
\text { delivery to ensure } \\
\text { equitable access. }\end{array}$ \\
\hline $\begin{array}{l}\text { Al-Yasseen et } \\
\text { al. (2010) }\end{array}$ & $\begin{array}{l}\text { question- } \\
\text { naire \& gov't } \\
\text { websites } \\
\text { assessment }\end{array}$ & $\begin{array}{l}\text { prior } \\
\text { operational use } \\
\text { evaluation and } \\
\text { operational use } \\
\text { evaluation }\end{array}$ & $\begin{array}{l}60 \text { private } \\
\text { hospitals }\end{array}$ & $\begin{array}{l}\text { Two-thirds of private } \\
\text { hospital do not } \\
\text { gather any evidence } \\
\text { to establish IT/ } \\
\text { information systems } \\
\text { Most decision } \\
\text { makers do not place } \\
\text { much importance on } \\
\text { Information system }\end{array}$ & $\begin{array}{l}\text { Without adopting } \\
\text { formal operation } \\
\text { use evaluation the } \\
\text { cost of future health } \\
\text { informatics would } \\
\text { seem likely to be } \\
\text { less accurate }\end{array}$ \\
\hline $\begin{array}{l}\text { Kirmaro et al. } \\
(2007)\end{array}$ & $\begin{array}{l}\text { Compara-tive } \\
\text { case study }\end{array}$ & $\begin{array}{l}\text { Determining } \\
\text { the } \\
\text { sustainability } \\
\text { of HIS }\end{array}$ & & $\begin{array}{l}\text { Misalignment of the } \\
\text { interest group(MOH, } \\
\text { donor,\& developer) } \\
\text { Lack of roles \& } \\
\text { responsibilities of } \\
\text { the actors }\end{array}$ & $\begin{array}{l}\text { Effective } \\
\text { collaboration } \\
\text { between interest } \\
\text { groups is } \\
\text { fundamental to } \\
\text { sustainability of HIS } \\
\text { Skills capacity } \\
\text { building for users, } \\
\text { managers and } \\
\text { planners. Build } \\
\text { conducive working } \\
\text { environment }\end{array}$ \\
\hline $\begin{array}{l}\text { Kossi et al. } \\
(2013)\end{array}$ & $\begin{array}{l}\text { Participa- } \\
\text { tory action } \\
\text { research }\end{array}$ & $\begin{array}{l}\text { Developing } \\
\text { health } \\
\text { information } \\
\text { system }\end{array}$ & & $\begin{array}{l}\text { Involvement of } \\
\text { communities on the } \\
\text { development and } \\
\text { use of HIS were the } \\
\text { main contributors } \\
\text { of the success. } \\
\text { Sharing data among } \\
\text { the community in } \\
\text { a transparent and } \\
\text { competitive manner. }\end{array}$ & $\begin{array}{l}\text { Modern ICT and } \\
\text { internet technology } \\
\text { are appropriate } \\
\text { technology even for } \\
\text { rural communities } \\
\text { in Africa. National } \\
\text { standardisation of } \\
\text { HIS, community HIS } \\
\text { to be connected to } \\
\text { national HIS and } \\
\text { routine feedback in } \\
\text { place }\end{array}$ \\
\hline
\end{tabular}




\begin{tabular}{|c|c|c|c|c|c|}
\hline $\begin{array}{l}\text { Farah et al } \\
(2011)\end{array}$ & $\begin{array}{l}\text { Qualitative- } \\
\text { case study } \\
\text { design }\end{array}$ & & 15 interviews & $\begin{array}{l}\text { PHC Information } \\
\text { systems run without } \\
\text { coordination. This } \\
\text { created redundancy } \\
\text { of data, wasting of } \\
\text { time \& resources. } \\
\text { Stakeholders' } \\
\text { resistance to } \\
\text { change. Absence } \\
\text { of essential data } \\
\text { sets was challenged } \\
\text { by the existing } \\
\text { organizational \& } \\
\text { political context }\end{array}$ & $\begin{array}{l}\text { Empowerment } \\
\text { of HIC through } \\
\text { further funding; } \\
\text { scale up staff } \\
\text { technical capacity. } \\
\text { Standardization of } \\
\text { procedures. His } \\
\text { integration with } \\
\text { commitment and } \\
\text { participation of } \\
\text { stakeholders } \\
\text { Introduction of } \\
\text { change in a piece- } \\
\text { meal fashion }\end{array}$ \\
\hline $\begin{array}{l}\text { Bruke et al. } \\
(2014)\end{array}$ & $\begin{array}{l}\text { Cross- } \\
\text { section } \\
\text { design }\end{array}$ & $\begin{array}{l}\text { Assessing } \\
\text { health } \\
\text { professionals } \\
\text { readiness to } \\
\text { use electronic } \\
\text { Medical record } \\
\text { system(EMRS) }\end{array}$ & $\begin{array}{l}606 \\
\text { participants }\end{array}$ & $\begin{array}{l}\text { Health professional } \\
\text { readiness to EMRS } \\
\text { was } 54.1 \% \text { and to } \\
\text { use } 46.5 \% \text {. Gender, } \\
\text { knowledge, attitude } \\
\text { and computer } \\
\text { skills were the } \\
\text { determinant factors } \\
\text { for lower readiness } \\
\text { and utilisation of } \\
\text { EMRS }\end{array}$ & $\begin{array}{l}\text { Increase awareness, } \\
\text { knowledge and } \\
\text { skills of health } \\
\text { professionals on } \\
\text { EMRS is crucial. }\end{array}$ \\
\hline
\end{tabular}

Table 2: Data extraction from text/expert opinion and guidelines papers

\begin{tabular}{|c|c|c|c|c|}
\hline Author (Ref.) & $\begin{array}{l}\text { Publica-tion } \\
\text { type }\end{array}$ & Aim & Summary/conclusion & Recommendations \\
\hline WHO (2008) & $\begin{array}{l}\text { Frame-work } \\
\text { and stan- } \\
\text { dard }\end{array}$ & $\begin{array}{l}\text { Increase } \\
\text { quality, value } \\
\text { and use } \\
\text { of health } \\
\text { information }\end{array}$ & $\begin{array}{l}\text { inputs ( resources); process } \\
\text { (indicators, data sources, data } \\
\text { management) and outputs } \\
\text { (information product, } 6 . \\
\text { dissemination and use) }\end{array}$ & $\begin{array}{l}\text { Developing standard provide } \\
\text { the } \\
\text { components of an information } \\
\text { system: } \\
\text { inputs, process and outputs }\end{array}$ \\
\hline WHO (2005) & $\begin{array}{l}\text { MHIS } \\
\text { guidelines }\end{array}$ & $\begin{array}{l}\text { Guideline } \\
\text { to assist } \\
\text { HIS policy- } \\
\text { makers and } \\
\text { planners }\end{array}$ & $\begin{array}{l}\text { Information on the } \\
\text { characteristics of the patient; } \\
\text { the nature of the problem } \\
\text { suffered by the patient; different } \\
\text { interventions delivered to the } \\
\text { patient; and how much the } \\
\text { patient's condition changed. }\end{array}$ & $\begin{array}{l}\text { Guideline to develop their own } \\
\text { HIS. The MDS (information } \\
\text { content) contains patient } \\
\text { characteristics, nature of the } \\
\text { problem, intervention and } \\
\text { change in condition }\end{array}$ \\
\hline $\begin{array}{l}\text { RHINO } \\
(2006)\end{array}$ & $\begin{array}{l}\text { Workshop } \\
\text { paper }\end{array}$ & $\begin{array}{l}\text { To establish } \\
\text { principles } \\
\text { and } \\
\text { strategies } \\
\text { of HIS \& } \\
\text { network }\end{array}$ & $\begin{array}{l}\text { Cross-cutting issues: (1) } \\
\text { information design and } \\
\text { demand; (2) data quality; (3) } \\
\text { information use; (4) quality } \\
\text { of services; (5) ICT; (6) } \\
\text { integration; and (7) information } \\
\text { system management. }\end{array}$ & $\begin{array}{l}\text { Improve community } \\
\text { participation on information } \\
\text { needs, feedback and } \\
\text { community information culture, } \\
\text { and network, monitoring } \\
\text { systems }\end{array}$ \\
\hline
\end{tabular}




\begin{tabular}{|c|c|c|c|c|}
\hline $\begin{array}{l}\text { Aqil, } \\
\text { Lippe-veld } \\
\text { \& Hozumi } \\
\text { (2009) }\end{array}$ & $\begin{array}{l}\text { Innova-tive } \\
\text { approach to } \\
\text { design }\end{array}$ & $\begin{array}{l}\text { Developing } \\
\text { a framework } \\
\text { for effective } \\
\text { use of } \\
\text { routine HIS }\end{array}$ & $\begin{array}{l}\text { Three determinant factors: } \\
\text { environmental, technical } \\
\text { and behavioural. These } \\
\text { determinants play the input } \\
\text { role in the routine HIS } \\
\text { process, improved routine HIS } \\
\text { performance as an output, } \\
\text { and outcome is improved } \\
\text { health systems performance, } \\
\text { and impact is improved health } \\
\text { status. }\end{array}$ & $\begin{array}{l}\text { Development of framework for } \\
\text { strengthening or reforming the } \\
\text { routine HIS } \\
\text { and provide a paradigm shift by } \\
\text { emphasising routine HIS } \\
\text { performance }\end{array}$ \\
\hline DoH (2011) & $\begin{array}{l}\text { DHIS policy } \\
\text { review }\end{array}$ & $\begin{array}{l}\text { Developing } \\
\text { a policy to } \\
\text { enhance the } \\
\text { performance } \\
\text { of the DHIS }\end{array}$ & $\begin{array}{l}\text { Limited alignment between goal } \\
\text { and objectives of health sector, } \\
\text { lack of indicators; inadequate } \\
\text { involvement of managers; poor } \\
\text { data validation, feedback and } \\
\text { use; shortage of experienced } \\
\text { information personnel; } \\
\text { inadequate ICT infrastructure; } \\
\text { limited or no tools, limited } \\
\text { knowledge and skill on the use } \\
\text { of basic software }\end{array}$ & $\begin{array}{l}\text { Involvement of managers, } \\
\text { timely } \\
\text { feedback and utilisation, } \\
\text { experienced information officer, } \\
\text { ICT infrastructure are essential }\end{array}$ \\
\hline
\end{tabular}

The systematic review was conducted to identify the use of information technology in processing health information in resource limited settings. Through examination of the different study and text/guidelines papers, the following factors appeared repeatedly as challenges in the use of information technology in resource limited settings: limited resources for health information systems and network development, lack of information users' involvement in the development of health information systems, poor understanding about the importance of quality health information processing and utilisation, lack of standardised indicators and contents.

\section{Limited resources for health information systems development}

Several studies have looked at the lack of resources, such as finance, inadequate equipment, skilled human resources, organisational support, and unavailability of internet and networking. The lack of resources contributed to the limited health information technology development including technical resources and lack of well-developed functioning health system. Furthermore, the lack of sustainable resources limit the design and development of the monitoring and evaluation system, infrastructure for electronic health recording and processing system as well as financial and organisational resources (DOH, 2011; Vital Wave, 2009; RHINO, 2006; WHO, 2004). Most decision makers do not place much importance on the development of information technology (Yaseen, Al-Japhoub, Al-shorbaji \& Salim, 2010). Kimaro and Nhampossa (2007) note that the collaboration between $\mathrm{MOH}$, Donors \& Software agency are important in the development of effective health information technology in resource limited settings. Apart from resource constraints 
and inadequate infrastructure, politics, cultural and social factors, and conflict of interest with health professional were mentioned in the literature as the barriers of information technology development (Oak, 2007).

\section{Information users' involvement in the development of health information systems}

Five papers reported on the lack of information users' (health managers, professional nurses and allied health workers) involvement on the health information needs and development. For instance, the involvement of health information technologist, health care providers and health managers was very minimal in the design and development of health information system. The information users are the main contributors to success of health information technology development (Kossi, Saebo, Braa, Jalloh \& Manya, 2013). However, there was misalignment of the interests, role and responsibilities of the actors in the process of information technology development (Kimaro \& Nhampossa, 2007). Additionally, health information needs were not established; there was lack of involvement of information system developers to design systems that are suitable to the local context; and uses of information culture were not developed among the health care providers community in resource limited settings. This in turn affected access to relevant information for effective health care delivery. These include access to evidence-based information, electronic journal and grey literature in clinical assessment and management of health problems (Health and Social Care, 2012; DOH, 2011; Chetley et al., 2006; RHINO, 2006; Odhiambooteino, 2005).

\section{Understanding the importance of quality health information processing and utilisation}

The use and importance of health information was not well understood by health care providers, particularly nurses who are drivers of primary health care services. Six studies reported duplications of data collection; data missing, fragmented, redundant and poor quality data were captured as well as little or no use of information (DOH 2011; Fraser, Bjune, Damtew \& Abdelziz, 2011; Aquil et al., 2009; Garrib et al., 2008; RHINO 2006). The environmental, technical and behavioural factors play a great role in the performance improved health information collection, processing and utilisation (Aqil et al., 2009). The review revealed that health care providers believe health information processing is an administrative job, not a health care professional task. Most health professionals in resource limited settings lack knowledge, skills, attitudes and values about the process and utilisation of health information. This was due to lack of formal training on health information or in-service training for health 
professionals and health managers on the process and use of health information, including guidance on data collection, process, interpretation \& utilisation. In addition even in the health settings where there was some technology available for electronic health information capturing and processing, there were shortages of skilled technical personnel to transfer the manual to electronic information processing. Shortage of staffing, load of patients and time constraints were mentioned as the major barriers for nurses to engage with information needs and processing. The development of essential data sets can also be challenged by the existing organisational, cultural and political contexts (Fraser et al., 2011). Biruk, Yilma, Andualem and Tilahun (2014) identified gender, knowledge and attitudes and unavailability of computer were the determinant factors for the lower readiness and utilisation of the system.

\section{Standardised indicators and content health information}

Sources of the information, accessibility, relevance, trustworthiness, currency, quality and reliability can determine whether information is met or not the purpose. Eight review papers identified the importance of developing guidelines on the standardised indicators and contents of data collection and process, particular at the primary health care facilities (Health and Social Care, 2012; Australian Institute of Health \& Welfare, 2012; DOH, 2011; Garrib et al., 2008; WHO, 2008; 2005; 2004). The review papers reported that health care facilities in similar areas or regions collect different health information. This was due to lack of standard information collection tools, with little or no known purposes. There were no health indicators (minimum data set) such as patient characteristics, identified problems, intervention and change as the result of intervention within or across the health facilities. Moreover, the use of information technology to facilitate processing health information requires a consensus adaptation of minimum data set indicators at national, provincial and at primary health care levels to guide nurses on how and what to collect. The lack of standardised indicators resulted in the inconsistent, fragmented, poor quality, unreliable and unusable health information being collected and processed. This in turn has an impact on the use of available information technology in processing quality information for sound policy formulation and health care deliveries. Additionally the lack of electronic recording system resulted in people to live in a mess and with disorganised health information processing system, such as a bunch of information storage scattered around or widely dispersed information resources, duplications, and gaps in information collection and fragmentation. A study has shown that the use of information technology with standardised indicators is essential for timely, reliable and accurate information collection and processing. For example, in an early outbreak of diseases, it is critical for preventing or taking early response measure before the damage has happened, especially in countries that are more economically vulnerable (Chetley et al., 2006). 
It enables remote consultation of diagnosis and treatment, and collaboration among the health workers including sharing information, monitor the incidence of public health threats and responds in more timely and effective manner (Chetley et al., 2006).

\section{DISCUSSION}

\section{Health information technology and network development}

This review highlighted infrastructure and network systems as the foundation of a health information system. It is impossible to have standards, consistent and accurate collection and exchange of health information across the health system and services without the necessary resources to develop information infrastructure and network system (Chetley et al., 2006; WHO, 2012). Health information technology requires adequate resources for the development and electronic information exchange across geographical and health sector boundaries of the health care services and applications that underpin the national electronic health environment. It provides a tangible means for enabling services and systems, access to exchange and management of information and content. There are several barriers identified to implementing health informatics, such as identified financial constraints, income disparities, inadequate resources, politics, infrastructure, professional behaviour and limited use of new technologies (WHO, 2012; Vital Wave Consulting, 2009; Oak ,2007). Similarly a study by Kalpa (2012) on the health information technology in the Indian health care system indicated various challenges and issues around the involvement of information technology, such as unavailability of internet facilities in all geographical areas and the absence of policy guidelines, infrastructure and competent human resources.

The use of health technology and standardisation of information collection systems enable the storage of health data sets using data structure, exchange of structured data, unique identification of individuals, healthcare providers and health care organisations and secure transmission of health information between healthcare providers (Aqil, Lippe-veld \& Hozumi, 2009; Chetley et al., 2006). It also enables the consistent and accurate collection and exchange of health information across geographical and health sectors (RHINO, 2006; WHO, 2008; 2012). Without these components health information cannot be collected consistently; usually it leaves rooms for misinterpretation and difficult to share health information due to incompatibilities in data structure and terminologies.

This review identified that professional nurses and midwives in resource limited settings do not have computers and network-based communication. Adoption of information technology is limited to only managerial and administrative staff. However, some segments of health services run by professional nurses and midwives, such as HIV/AIDS clinics in South Africa, have computers for data collection and reporting. Although mobile devices are one of the fastest developing key enablers for 
HIS, network coverage has expanded extensively and reached most of the population of the world, the capacity and coverage of data connectivity and networking, such as mobile phone coverage across the health system are not available in resource limited settings

\section{Information users' involvement in the design and development of HIS}

The systematic review of this study identified that the successful outcomes of the use of information technology are determined by the involvement of community and stakeholders - mainly professional nurses and midwives in the design and implementation of the health information system at primary and community health care levels in resource limited settings. However, Odhiambo-Otieno (2005) argues that the district health information system failed due to lack of involvement of the health managers and health workers in the design and implementation of the district health information systems. The author emphasises that when the project is designed and developed at higher levels and dictated down for implementation by ignoring the importance of involving the users (particularly professional nurses and midwives) in the design and development, implementation is always challenging. Another study in Uganda has shown lack of information distribution benefits, segregated demographic data and social value as the determinant factor in information seeking behaviour of health professionals (Kapiriri \& Bondy, 2006). Similarly, a study by Garrib et al. (2008) argues that the data should meet the needs of users both at local and national level, where the needs of the users can only be understood through involving them in the design and development. Aqil et al. (2009) and RHINO (2006) emphasise the importance of community participation in assessing community health information needs, developing a community information sharing culture, and creating a network that links community health needs to healthcare providers could improve the quality of information processing and utilisation, and this in turn has positive impacts on the outcomes of health services. The main contributors to success of health information systems are the involvement of the communities in the development and sharing health information in a transparent manner (Kossi, Saebo, Braa, Jalloh \& Manya, 2013). The study suggested that the community HIS should be connected to the national HIS and routine feedback to the community in the form of analysis is essential for the appropriate use of information technology (Kossi et al., 2013). On the other hand, Farah, Bujne, Damtew and Abdelaziz (2011) identified stakeholders resistance as the barriers of integrating HIS both vertically and horizontally. One way of addressing this barrier is through introducing changes in a piece-meal manner.

The feedback mechanism on health information collected and analysed to the community of health care providers is an incentive to motivate data operators and users, professional nurses and midwives to improve the quality of the data and 
utilisation (Nandan, 2010). Moreover, a clear understanding of community needs motivates collection of better data to address those needs. The top-down health information systems resulted in many challenges, such as poor coordination of leadership and lack of health worker participation and understanding the value of data and needs (Hendy et al., 2005). However, experiences of some countries indicated that the bottom-up health information model, which involves community healthcare workers, in this case professional nurses and midwives, shares best practices in system implementation. Empowering community health workers through feedback and participatory mechanisms made the health delivery system more responsive to the healthcare needs of the population (Nandan, 2010).

\section{Professional behaviour and capacity development}

Over the years several research outcomes on health information systems in developing countries indicated the lack of skilled personnel in health information processing and utilisation, and the lack of alignment between goals and objectives in the health sectors (Biruk, et al., 2014; Farah et al., 2011; DOH, 2011;Kimaro \& Nhampossa, 2007; Oak, 2007). This resulted in limited availability of health data for policy formulation, scientific research and for health care delivery. Vital Wave Consulting (2009) identified poor data quality as a serious problem, and data streamlining and validation of data efforts are problematic in resource limited countries. One of the primary reasons contributing to the poor data quality was poor knowledge, and skills of health professional in information processing and utilisation (Hendy et al., 2005), particularly those responsible for service provision, such as doctors, nurses and midwives. Capacity development through skills training of health workers, health managers and information officers on data collection, analysis, interpretation, data concept development and utilisation is one of the crucial factors in the HIS (Chetley et al., 2006; WHO, 2005 ). Skills training is key to the behavioural factors in determining the success of HIS. Although training was not discussed in detail, the type of training reflected was technical skills related to use of the system, training related to the use of information and the application of principles of quality improvement programmes. It was highlighted that capacity building through sufficient education should not only assist them on how to work with the HIS, but also why it should be used. Knowledge of why it is necessary to use the new system is crucial, because the health care providers are concerned with the load of managing clinical needs (Littlejohn et al., 2003).

Apart from the importance of knowledge and skills improvement in the information system, RHINO (2006) notes that the heartbeat of any routine HIS is the motivated health care workers. As data collection is not their primary task, they wanted to know what incentives exist for staff members in data collection. Incentives are not always monetary but symbolic; most workers are given frequent feedback 
and made to feel that their work is important. Routine health worker training to improve their knowledge and skills on an electronic medical record system and strong management support could address issues around health workers' motivation for data collection and use (Biruk, Yilma, Andualem \& Tilahun, 2014; RHINO, 2006).

\section{Standardised indicators and contents}

The term information processing involves inputs, process, outputs, outcomes and feedback. Apart from challenges of technical, human, financial, infrastructure and behaviour inputs, information inputs such as the minimum data set, standard information collection tools and content and indicators are not mostly available in resource limited areas (Aqil et al., 2009; WHO, 2004). Developing consensusbased minimum data set and standard collection tools are crucial for processing and utilisation of quality information. The amount of information processing and utilisation is usually minimal at primary healthcare level. The Australian Institute of Health and Welfare (2012), Health and Social Care Information Centre (2012), Vital Wave Consulting (2009) and Aqil et al. (2009) argue that to improve data quality and useability, it is crucial to develop a minimum data set and standard for community health care level. Some of the community health care have fewer categories of data collection and reporting systems than others based on the local context, such as mandatory, required and optional reporting systems. Understanding of the indicators by the community health nurses and midwives reduces duplication and improves quality data. It was recommended that the consensus adaptation of a minimum data set can be established in resource limited settings, based on the common data needs. It is usually designed to reflect the rich complexity of patient needs. As patients' needs change, a review of the minimum data set should also be changed. The minimum data set includes elderly patients, who receive specialist health services. This is identified as the total period during which the patient receives care from specialist health staff, comprising outpatient attendance over a few weeks, or extended for many years, and includes hospital, community, outpatient and day care episodes.

The minimum data set record comprises characteristics of the patient, including where they live, the nature and extent of the problems, the different interventions given, health and local organisations involved, and the change in the patient's condition over time (Australian Institute of Health and Welfare, 2012; Health and Social Care Information Centre, 2012). The authors also suggested that periodical updating of the minimum data set is necessary as the need arises. Addressing the issue of incentives in the form of feedback surrounding data collection improves the quality of data collection and processing (Vital Wave Consulting, 2009). Although quality of data is not primarily a technological issue, technology can assist in improving it. Therefore, the poor quality of data is largely due to the burden of 
existing data collection and lack of knowledge and incentives in resource limited settings. The technology can do little in terms of accurate reporting.

This review identified challenges of processing and utilisation of health information in source limited settings. It also highlighted the importance of HIS to provide healthcare providers structured information they need for quality care and education to their patients and the community. The degree of utilisation of health information at lower levels is limited, even for those who developed a minimum data set for health recording and reporting. Information processing itself requires indicators, computers with software for data analysis, data sources, data collection, data management, quality checking, transmission and feedback. It also requires skilled and experienced personnel to process the quality information timeously. Furthermore, the data quality check process requires dedicated and experienced data managers as far down as the primary health care level that can identify and analyse data and work with professional nurses and midwives to improve data collection and quality. Feedback is another key process for identifying problems for solution, empowering the health workers to use data, for regulating and improving performance at individual and system levels, and for identifying opportunities for learning. It is important for professional nurses and midwives to realise the challenges that are experienced in resource limited settings in the use of information technology in processing and utilisation of health information.

\section{CONCLUSION}

The outcomes of the review have demonstrated challenges in the use of information technology in processing and utilisation of health information in resource limited settings. The utilisation of health information technology is determined by local conditions; technology should be user friendly and sustainable; no single technology will be suitable for all situations. In resource limited settings, many healthcare providers and health information officers use manual information recording and processing system. However, literature evidence has shown that manual way of information processing is not adequate enough to process quality information. Therefore, combining manual recording and information processing system and the use of information technology in recording and processing health information in creative and innovative way is essential for improving the quality of health information processing, and utilisation in resource limited settings. Professional nurses and midwives are at the forefront of health care providers in resource limited settings, providing a continuous capacity development training on health information systems and involving them in the design and development of health information processing tool and utilisation could enhance the gradual transformation of manual information recording and processing system into information technology based recording and processing of health information. In addressing the health information 
need of the community in resource limited settings, develop a clear sustainable plan, establish infrastructure and network system, and identify good health information practices. It is crucial for government to highlight and set the priority needs and provide support on addressing those priority issues related to utilisation of appropriate health information technology, and improve communication strategies in the design of health information systems for effective and equitable health deliveries.

\section{LIMITATIONS}

One of the first limitations of this work is a publication bias. Papers that are not written in English were excluded. Limited resource settings have very low research outputs and publications on health information processing and utilisation, and as a result it was necessary to incorporate non-research papers such as expert opinions and government or organisation policy guidelines papers that are relevant to the purpose of the review.

\section{CONFLICT OF INTEREST}

There is no potential conflict of interest relevant to this article to report.

\section{ACKNOWLEDGEMENT}

The author would like to thank Dr. Marie-Modeste for contributing to this review. I would like to extend my gratitude to the anonymous reviewers for their critical comments to improve the quality of this paper.

\section{REFERENCES}

Al-Yaseen, H., Al-Jaghoub, S., Al-Shorbaji,M. \& Salim, M. 2010. Post implementation evaluation of health care information systems in developing countries. The Electronic Journal Information Systems Evaluation, 13(1):9-16.

Aqil, A., Lippeveld, T., \& Hozumi, D. 2009. PRISM framework: A paradigm shift for designing, strengthening and evaluating routine health information systems. Health Policy and Planning, 24:217-228.

Australian Institute of Health and Welfare. 2012 Community mental health care National Minimum Data Set (NMDS). Retrieved from http://www.aihw.gov.au/publicationdetail/?id=6442467505 (Accessed 14 March 2013).

Biruk, S., Yilma, Y., Andualem, M. \& Tilahun, B. 2014. Health professionals readiness to implement electronic medical record system: A cross-sectional design. BMC Medical Informatics and Decision Making, 14:15. 
Chetley, A., Davis, J., Trude, B., McConnell, H., Ramirez, R., Shield, T., Drury, P., Kumekawa, J., Louw, J., Fereday, G. \& Nyamai-kisia, C. 2006. Improving health, connecting people: The role of ICTs in health sector of developing countries. Retrieved from www.healthlink.org.uk (Accessed 10 June 2014).

Department of Health. 2011. District health management information system policy. Retrieved from www.doh.gov.za (Accessed 12 December 2012).

European Commission. 2004. e-Health - Making healthcare better for European citizens: An action plan for a European e-Health area. Retrieved from http://ec.europa.eu/informationsociety/ doc/qualif/health/COM 20040356 FENCTE.pdf (Accessed 13 October 2013).

Farah, S.K.S., Bujune, G.A., Damtew, Z.A.\& Abdelaziz, A.O. 2011. Challenges \& opportunities on integrating primary health care information system in the Northern state Sudan. Sudanese Journal of Public health, 6(3).

Garrib, A., Stoops, N., Mckenzie, A., Delamini, L., Govender, T., Roohde, J. \& Herbst, K. 2008. An evaluation of the district health information system in rural South Africa. South African Medical Journal, 98(7):549-522.

Goldschmidt, P.G. 2005. HIT and MIS: Implication of health information technology and medical information systems. Communications of the ACM, 48(10):69-74.

Haux, R. 2006. Health Information Systems - past, present, future. International Journal of Medical Informatics, 75:268-281.

Hayrinen, K., Saranto, K. \& Nykänen, P. 2008. Definition, structure, content, use and impacts of electronic health records: A review of the research literature. International Journal of Medical Informatics, 77:291-304.

Health and Social Care Information Centre. 2012. The health and social care information centre annual report and accounts. Retrieved from http://www.official-documents.gov.uk/ document/hc (Accessed 12 March 2013).

Hendy, J., Reeves, B.C., Fulop, N., Hutchings, A. \& Masseria, C. 2005. Information in practice. Challenges to implementing the National Programme for Information Technology (NPfIT): A qualitative study. British Medical Journal.

Kapiriri, L. \& Bondy, S.J. 2006. Health practitioners and health planners information needs and seeking behaviour for decision making in Uganda.

Kimaro, H.C. \& Nhampossa, J.L. 2007. The challenges of sustainability of health information systems in developing countries: Comparative case studies of Mozambique and Tanzania. Journal of Health Informatics in Developing Countries, 1(1):1-10.

Kossi, E.K., Saebo, J.I., Braa, J., Jalloh, M.M. \& Manya, A. 2010. Developing decentralized health information systems in developing countries-case from Sierra Leone and Kenya. Journal of Community Informatics, 9(2).

Littlejohn, P., Wyatt, J.C. \& Garvican, L. 2003. Evaluating computerised health information systems: Had lessons still to be learnt. British Medical Journal, 326:860-863.

Jensen, J.D., King, A.J., Guntzviller, L.M. \& Davis, L.A. 2010. Patient-provider communication and low-income adults. Age, ace, literacy, and optimism predict communication satisfaction. Patient Education and Counseling,79:30-35.

Nandan, D. 2010. National rural health mission: Turning into reality. Indian Journal of Community Medicine, 35(4):453-453. 
Oak, M.R. 2007. A review on barriers to implementing health informatics in developing countries. Journal of Health Informatics in developing countries, 1(1):19-22. Retrieved from http:// www.jhidc.org/index.php/jhidc/article vie/3

Odhiambo-Otieno, G.W. 2005. Evaluation of existing district health management Information Systems in Kenya. International Journal of Medical Informatics, 74:733-744.

Richard, L.S. \& Ronald, M.E. 2008. Lesson from theory and research on clinician-patient communication. In G. Karen, K.R. Barbara, K. Viswanth (Eds.), Health behaviour and Health Education; theory, research, and practice ( $4^{\text {th }}$ ed.), 236-269. San Francisco, CA: Jossey Bass.

Routine Health Information Network Organization. 2006. Third International RHINO Workshop Information for Action. Facility and community focus, February 26-March3, 2006, Chiang Rai, Thailand. Retrieved from www.cpc.unc.edu/measue (Accessed 16 November 2012).

Vital Wave Consulting. 2009. Health information systems in developing countries: A landscape analysis. Retrieved from www.vitalwaveconsulting.com/.../gate-Foundation (Accessed 18 November 2012).

World Health Organization. 2005. Mental health information system. Mental health policy and guidance package. Geneva: WHO.

World Health Organization. 2008. Framework and standards for country health information systems ( $2^{\text {nd }}$ ed.). Geneva: Health Metrics Network. Retrieved from http//www.healthmetricsnetwork. org (Accessed 20 May 2012).

World Health Organization. 2012. National eHealth Strategy Toolkit part 2: Developing a national eHealth Action Plan. World Health Organization and International Telecommunication Union. Retrieved from www.who.int (Accessed October 2013). 